ISSN 0258-7122 (Print), 2408-8293 (Online)

Bangladesh J. Agril. Res. 41(4): 713-723, December 2016

\title{
EFFECT OF SPACING AND FERTILIZER MANAGEMENT ON THE YIELD AND YIELD ATTRIBUTES OF MUKHIKACHU (Colocasia esculenta Schott.)
}

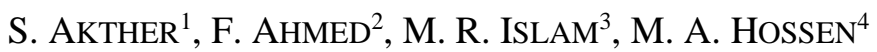 \\ AND A. H. M. M. RAHMAN TALUKDER ${ }^{5}$
}

\begin{abstract}
Field experiments were carried out in the Agronomy field of BARI, Joydebpur, RARS, Jamalpur and RARS, Ishurdi during two consecutive kharif seasons of 2012 and 2013 to determine the suitable plant spacing and optimum fertilizer dose for higher yield of mukhikachu. Three levels of spacing viz., $60 \mathrm{~cm} \mathrm{x} 60$ $\mathrm{cm}, 60 \mathrm{~cm} \times 45 \mathrm{~cm}$ and $60 \mathrm{~cm} \times 30 \mathrm{~cm}$ and three levels of fertilizer dose viz., recommended dose (3000-96-27-81-18 $\mathrm{kg} \mathrm{ha}^{-1}$ of CD-N-P-K-S), 25\% less than the recommended dose and $25 \%$ higher than the recommended dose were used as treatment variables. The experiments were laid out in factorial randomized complete block design with three replications. Results revealed that the closer spacing $(60 \mathrm{~cm} \times 30 \mathrm{~cm})$ in combination with $25 \%$ higher than the recommended fertilizer dose gave the maximum edible yield of mukhikachu (two years average) at all locations (20.04 t ha-1, $20.75 \mathrm{t} \mathrm{ha}^{-1}$ and $16.63 \mathrm{t} \mathrm{ha}^{-1}$ at Joydebpur, Jamalpur and Ishurdi, respectively). The wider spacing (60 cm x 60 $\mathrm{cm}$ ) coupled with $25 \%$ less than the recommended fertilizer dose produced the lowest yield (two years average). The maximum benefit- cost ratio (two years average) was obtained from the combination of the recommended fertilizer dose and $60 \mathrm{~cm} \times 30 \mathrm{~cm}$ spacing, that were 2.93 at Joydebpur and 3.42 at Ishurdi, while at Jamalpur the maximum benefit-cost ratio (two years average) was found maximum from $60 \mathrm{~cm} \times 30 \mathrm{~cm}$ spacing with $25 \%$ higher than the recommended fertilizer dose (3.12).
\end{abstract}

Keywords: Mukhikachu, spacing, fertilizer, yield, benefit-cost ratio, Colocasia esculenta schott

\section{Introduction}

Mukhikachu (Colocasia esculenta Schott) is an important tuber crop vegetable grown in kharif season in Bangladesh. It belongs to the family Araceae and is well known as taro. It is a carbohydrate, protein and iron and vitamin 'A' rich vegetable which is generally grown during February/March to September/October (Salam, 2003). It is considered as an important vegetable, particularly in the month of August-October when the supply of other vegetables is scarce in the market (Siddique et al., 1988; Basak and Maleque, 1992). The area and gross annual production of mukhikachu in Bangladesh is increasing year after year, but its yield

${ }^{1}$ Scientific Officer, Agronomy Division, Bangladesh Agricultural Research Institute (BARI), Gazipur, '2Principle Scientific Officer, Physiology Division, BARI, Gazipur, ${ }^{3}$ Senior Scientific Officer, RARS, BARI, Ishurdi, ${ }^{4}$ Ex-Scientific Officer, BARI, Gzipur, ${ }^{5}$ Scientific Officer, RARS, BARI, Jamalpur, Bangladesh. 
per unit area is low $\left(9.76 \mathrm{tha}^{-1}\right)(\mathrm{BBS}, 2011)$ as compared with China $\left(17.05 \mathrm{t} \mathrm{ha}^{-1}\right)$ and Japan (11.59 $\left.\mathrm{t} \mathrm{ha}^{-1}\right)$ (FAO, 1999). Too low or wider spacing and unbalanced fertilizer might be two important factors for this low yield of mukhikachu. It is reported that its yield usually varied with different plant densities (Atikuzzaman, 2008; Suminarti et al., 2016; Sikder et al., 2014). Suitable plant spacing can lead to optimum yield whereas too high or too low plant spacing could result in relatively low yield and quality. Application of fertilizer has great impact on growth and yield of crop plants. The requirement of fertilizer for any crop varies with cultivars, plant population and soil type in AEZs (Mitra et al., 1990). The tendency of the Bangladeshi farmers is to use closer spacing and high amount of nitrogenous fertilizer because they think that more the plant population with vigorus vegetative growth due to $\mathrm{N}$ fertilization and more the yield of mukhikachu. Mukhikachu requires a high dose of nitrogen and potassium (Rashid, 1999; Bose and Som, 1986; Mohankumar et al., 1991) because nitrogen is essential for growth and potassium for starch formation and potassium exerts a blanching effect on both $\mathrm{N}$ and $\mathrm{P}$ and consequently important in mixed fertilizer. Potassium is very important for tuber formation because it is known to be essential for the synthesis and translocation of carbohydrate (Bose and Som, 1986). The present experiment was therefore, carried out to find out suitable plant spacing and optimum fertilizer dose for higher yield and maximum economic return in different AEZs.

\section{Materials and Method}

Field experiments were carried out in the Agronomy field of BARI, Joydebpur, Regional Agricultural Research Station (RARS), Jamalpur and RARS, Ishurdi of BARI during two consecutive Kharif seasons of 2012 and 2013. In 2012, during experimentation the average temperature of Gazipur, Ishurdi and Jamalpur was $29.04^{\circ} \mathrm{C}, 27.30^{\circ} \mathrm{C}$ and $24.22^{\circ} \mathrm{C}$, respectively whereas, in 2013 that were $28.60^{\circ} \mathrm{C}$, $28.25^{\circ} \mathrm{C}$ and $28.60^{\circ} \mathrm{C}$, respectively. In 2012 , the total rainfall of Gazipur, Ishurdi and Jamalpur was $1104.80,948.89$ and $1552.30 \mathrm{~mm}$, respectively, while in 2013, the total rainfall of Gazipur, Ishurdi and Jamalpur was 1583.60, 1172.72 and $1453.75 \mathrm{~mm}$, respectively. The initial soil analyses of Joydebpur, Ishurdi and Jamalpur are given in Table 1. At all locations the status of total $\mathrm{N}$ was very low and $\mathrm{P}$ was below critical level. At Ishurdi and Jamalpur, the amount of $\mathrm{K}$ was below the critical level whereas at Joydebpur the status of $\mathrm{K}$ was just above the critical level. At all locations the amount of $S$ was just above the critical level. Three levels of spacing i.e. $S_{1}=60 \mathrm{~cm} \times 60 \mathrm{~cm}, S_{2}=60 \mathrm{~cm} \times 45 \mathrm{~cm}$ and $S_{3}=60$ $\mathrm{cm} \times 30 \mathrm{~cm}$ and three levels of fertilizer dose i.e. $\mathrm{F}_{1}=$ recommended dose (300096-27-81-18 kg ha ${ }^{-1}$ of CD-N-P-K-S, FRG, 2005), $\mathrm{F}_{2}=25 \%$ less than the recommended dose and $\mathrm{F}_{3}=25 \%$ higher than the recommended dose were used as treatment variables in the present study.

The experiments were conducted in a factorial randomized complete block design with three replications. The unit plot size was $3.6 \mathrm{~m} \times 3.6 \mathrm{~m}$. The variety used in the experiment was 'Bilashi'. The crop was fertilized with as per treatment. 
Table 1. The initial soil analyses of Joydebpur, Ishurdi and Jamalpur before experimentation

\begin{tabular}{l|c|c|c|c|c|c}
\hline \multicolumn{1}{c|}{ Location } & $\mathrm{PH}$ & $\begin{array}{c}\mathrm{OM} \\
(\%)\end{array}$ & $\begin{array}{c}\text { Total } \\
\mathrm{N} \%\end{array}$ & $\begin{array}{c}\mathrm{P} \\
(\mathrm{ppm})\end{array}$ & $\begin{array}{c}\mathrm{K} \text { (meq./ } \\
100 \mathrm{~g} \text { soil })\end{array}$ & $\begin{array}{c}\mathrm{S} \\
(\mathrm{ppm})\end{array}$ \\
\hline Joydebpur & 6.25 & 0.62 & 0.10 & 8.64 & 0.23 & 17.30 \\
Ishurdi & 7.3 & 1.32 & 0.053 & 11 & 0.12 & 15 \\
Jamalpur & 5.6 & 1.79 & 0.094 & 5.60 & 0.10 & 17.0 \\
Critical level & - & - & - & 14 & 0.2 & 14 \\
\hline
\end{tabular}

The entire amount of phosphorous $(\mathrm{P})$, potassium $(\mathrm{K})$ and sulphur $(\mathrm{S})$ was applied as basal. $\mathrm{N}$ was applied at 15-20 and 40-45 days after planting. Cormel was planted in line. In the first year (2012), seed cormels of mukhikachu were planted on 11 March at Jamalpur, 12 March at Joydebpur and 30 March at Ishurdi and harvested on 12 December at Jamalpur, 30 August at Joydebpur and 9 December at Ishurdi and in the second year (2013), seed cormels of mukhikachu were planted on 23 March at Jamalpur, 21 March at Joydebpur and 16 March at Ishurdi and harvested at 4 November at Jamalpur, 30 October at Joydebpur and 28 November at Ishurdi. Intercultural operations were done as and when required. Ten plants were randomly selected from each plot for recording yield contributing characters. The yield data was recorded from an area of 12.96 $\mathrm{m}^{2}$ in each plot and per hectare yield was calculated. Secondary corms and cormels were considered to calculate yield data which were mentioned as edible yield. All the collected data were analyzed statistically and mean separation was done by the Least Significant Difference (LSD) at 5\% level of probability (Gomez and Gomez, 1984).

\section{Results and Discussion}

Number of secondary corms plant ${ }^{-1}$ : Different spacing in combination with fertilizer showed significant effect on number of secondary corms plant ${ }^{-1}$ at all locations except Jamalpur (Tables 2, $3 \&$ \& 4). At Joydebpur number of corms plant $^{-1}$ in different treatments were found identical in 2012 while that varied significantly in 2013 (Table 2). In 2012, number of corms plant ${ }^{-1}$ ranged from $4.07\left(\mathrm{~S}_{3} \mathrm{~F}_{2}\right)$ to $5.13\left(\mathrm{~S}_{2} \mathrm{~F}_{3}\right)$. In 2013 , the highest number of corms plant ${ }^{-1}$ recorded in $S_{1} F_{1}$ (5.13) which was significantly higher than $S_{2} F_{2}$ but statistically similar with all other treatments. The lowest number of corms plant ${ }^{-1}$ was obtained from $\mathrm{S}_{2} \mathrm{~F}_{2}$ (3.53) combination. At Jamalpur, number of corms plant ${ }^{-1}$ was not significantly varied in different treatments (Table 3). However, number of corms plant $^{-1}$ ranged from $3.40\left(\mathrm{~S}_{1} \mathrm{~F}_{2}\right)$ to $5.40\left(\mathrm{~S}_{1} \mathrm{~F}_{1}\right)$ in 2012 and in 2013, number of corms plant ${ }^{-1}$ ranged from $6.0\left(\mathrm{~S}_{1} \mathrm{~F}_{2}\right)$ to $8.13\left(\mathrm{~S}_{1} \mathrm{~F}_{1}\right)$. At Ishurdi, number of corms plant $^{-1}$ varied significantly in different treatments during both the years $(2012$ \& 2013) (Table 4). In 2012, the highest number of corms plant ${ }^{-1}$ was recorded in 
$\mathrm{S}_{1} \mathrm{~F}_{3}$ (5.20) which were identical to all other treatments except $\mathrm{S}_{3} \mathrm{~F}_{2}$. The lowest number of secondary corms plant ${ }^{-1}$ was obtained from $\mathrm{S}_{3} \mathrm{~F}_{2}$ (3.70) combination. In 2013, the highest number of corms plant ${ }^{-1}$ was recorded in $S_{1} F_{3}(5.86)$ which was closely followed by all other treatments except $S_{3} F_{1}$ and $S_{3} F_{2}$. The lowest number of secondary corms plant ${ }^{-1}$ was obtained from $\mathrm{S}_{3} \mathrm{~F}_{2}$ combination in both the years. Suminarti et al. (2016) reported that application of $125 \mathrm{~kg} \mathrm{~N} \mathrm{ha}^{-1}$ and $62 \mathrm{~kg} \mathrm{~K} \mathrm{ha}^{-1}$ gave the highest yield of mukhikachu (16.45 t/ha) and number of corms plant ${ }^{-1}$ decreased with the increase of plant population.

Weight of secondary corms plant ${ }^{-1}(\mathrm{~g})$ : Combination of spacing and fertilizer put significant effect on weight of secondary corms plant $^{-1}$ at all the locations (Tables 2, $3 \& 4$ ). At Joydebpur, different treatments did not differ significantly in respect of weight of secondary corms plant $^{-1}$ in 2012 while that varied significantly in 2013 (Table 2). In 2012, weight of secondary corms plant ${ }^{-1}$ ranged from $233.30 \mathrm{~g}\left(\mathrm{~S}_{3} \mathrm{~F}_{1}\right)$ to $274 \mathrm{~g}\left(\mathrm{~S}_{1} \mathrm{~F}_{3}\right)$ in different treatments. In 2013 , the maximum weight of secondary corms plant ${ }^{-1}$ was recorded in $\mathrm{S}_{1} \mathrm{~F}_{3}(232.90 \mathrm{~g})$ which was closely followed by $S_{1} F_{1}, S_{1} F_{2}, S_{2} F_{1}$ and $S_{2} F_{3}$. The lowest weight of secondary corms plant ${ }^{-1}$ was obtained from $\mathrm{S}_{3} \mathrm{~F}_{1}(198.30 \mathrm{~g})$ combination in 2013. At Jamalpur, weight of secondary corms plant ${ }^{-1}$ varied significantly in different treatments during both the years (2012 \& 2013) (Table 3). In 2012, the maximum weight of secondary corms plant ${ }^{-1}$ was recorded in $\mathrm{S}_{1} \mathrm{~F}_{3}(393.30 \mathrm{~g})$ closely followed by $S_{1} F_{1}$ and $S_{2} F_{3}$ and the lowest weight of secondary corms plant ${ }^{-1}$ was obtained from $\mathrm{S}_{3} \mathrm{~F}_{1}(206.70 \mathrm{~g})$ treatment. In 2013, the highest weight of secondary corms plant ${ }^{-1}$ was recorded in $\mathrm{S}_{1} \mathrm{~F}_{3}(456.60 \mathrm{~g})$ which was statistically similar with $\mathrm{S}_{1} \mathrm{~F}_{2}$ and $\mathrm{S}_{2} \mathrm{~F}_{1}$ combinations and the lowest weight of secondary corms plant ${ }^{-1}$ was obtained from $\mathrm{S}_{3} \mathrm{~F}_{1}(246.60 \mathrm{~g})$ combination. At Ishurdi, different combinations had significant effect on weight of secondary corms plant ${ }^{1}$ in both the years (2012 \& 2013) (Table 4). In 2012, the highest weight of secondary corms plant ${ }^{-1}$ was recorded in $\mathrm{S}_{1} \mathrm{~F}_{3}(135.50 \mathrm{~g})$ which was identical with $\mathrm{S}_{2} \mathrm{~F}_{3}$. The lowest weight of secondary corms plant ${ }^{-1}$ was obtained from $\mathrm{S}_{3} \mathrm{~F}_{2}$ (95 g) combination. In 2013, the highest weight of secondary corms plant ${ }^{-1}$ was recorded in $\mathrm{S}_{1} \mathrm{~F}_{3}(155.72 \mathrm{~g})$ which was identical with $\mathrm{S}_{2} \mathrm{~F}_{3}$ and the lowest weight of secondary corms plant ${ }^{-1}$ was obtained in $\mathrm{S}_{3} \mathrm{~F}_{2}(115.24 \mathrm{~g})$ treatment. Weight of corms plant ${ }^{-1}$ increased at wider spacing might be due to less competition for nutrients, moisture and light among the plants. Suminarti et al. (2016) obtained the highest yield of corms and cormels plant ${ }^{-1}$ from $60 \mathrm{~cm} \mathrm{x} 40 \mathrm{~cm}$ spacing. Sikder et al. (2014) also got the maximum and minimum individual corm from $60 \mathrm{~cm}$ x $50 \mathrm{~cm}$ and $60 \times 20 \mathrm{~cm}$ spacing, respectively.

Number of cormels plant ${ }^{-1}$ : Different spacing coupled with fertilizer treatment showed significant effect on number of cormels plant ${ }^{-1}$ at all locations (Tables 2, 3 \& 4). At Joydebpur, number of cormels plant ${ }^{-1}$ was found identical in different treatments in 2012 while that varied significantly in 2013 (Table 2). In 2012, 
number of cormels plant ${ }^{-1}$ ranged from $24.53\left(\mathrm{~S}_{3} \mathrm{~F}_{2}\right)$ to $28.4\left(\mathrm{~S}_{1} \mathrm{~F}_{3}\right)$ while in 2013 , the highest number of cormels plant ${ }^{-1}$ was recorded in $S_{3} F_{1}$ (14.93) which was statistically similar with all other treatments except $\mathrm{S}_{3} \mathrm{~F}_{2}$ and the lowest number of cormels plant ${ }^{-1}$ was obtained from $\mathrm{S}_{3} \mathrm{~F}_{2}$ (10.07) treatment in 2013. At Jamalpur, number of cormels plant ${ }^{-1}$ was found identical in different treatments in 2012 while that varied significantly in 2013 (Table 3). In 2012, number of cormels plant ${ }^{-1}$ ranged from $6.60\left(\mathrm{~S}_{3} \mathrm{~F}_{2}\right)$ to $9.90\left(\mathrm{~S}_{2} \mathrm{~F}_{1}\right)$ but in 2013 , the highest number of cormels plant ${ }^{-1}$ was recorded in $\mathrm{S}_{1} \mathrm{~F}_{1}(17.80)$ and the lowest number of cormels plant ${ }^{-1}$ was obtained from $\mathrm{S}_{3} \mathrm{~F}_{2}$ (9.50) treatment. At Ishurdi, different treatments varied significantly in terms of number of cormels plant ${ }^{-1}$ in both the years (2012 \& 2013) (Table 4). In 2012, the highest number of cormels plant ${ }^{-1}$ was recorded in $S_{1} F_{3}$ (16.88) which was statistically similar with $S_{1} F_{1}$ and the lowest number of cormels plant ${ }^{-1}$ was obtained from $S_{3} F_{2}$ (13.90) treatment. In 2013, the highest number of cormels plant ${ }^{-1}$ was recorded in $S_{1} F_{3}(17.46)$ which was identical with $S_{1} F_{1}$ and the lowest weight of number of cormels plant ${ }^{-1}$ was obtained from $\mathrm{S}_{3} \mathrm{~F}_{2}$ (14.48) treatment.

Weight of cormels plant ${ }^{-1}$ : Different spacing in combination with fertilizer treatments exerts significant effect on weight of cormels plant ${ }^{-1}$ at all locations (Tables $2,3 \& 4$ ). At Joydebpur, weight of cormels plant $^{-1}$ varied significantly in 2012 while did not vary significantly in 2013 (Table 2). In 2012, the highest weight of cormels plant ${ }^{-1}$ was recorded in $\mathrm{S}_{1} \mathrm{~F}_{3}(594 \mathrm{~g})$ which was statistically similar with $\mathrm{S}_{2} \mathrm{~F}_{1}$ and $\mathrm{S}_{2} \mathrm{~F}_{2}$ treatments and the lowest weight of cormels plant ${ }^{-1}$ was obtained from $\mathrm{S}_{2} \mathrm{~F}_{2}(534 \mathrm{~g})$ treatment. In 2013, weight of cormels plant ${ }^{-1}$ ranged from $400.50 \mathrm{~g}\left(\mathrm{~S}_{2} \mathrm{~F}_{2}\right)$ to $445.50 \mathrm{~g}\left(\mathrm{~S}_{1} \mathrm{~F}_{3}\right)$. At Jamalpur, weight of cormels plant $^{-1}$ varied statistically due to different treatments in both years (2012 \& 2013) (Table 3). In 2012, the maximum weight of cormels plant ${ }^{-1}$ was recorded in $\mathrm{S}_{2} \mathrm{~F}_{1}$ $(124.70 \mathrm{~g})$ which was statistically similar with $\mathrm{S}_{1} \mathrm{~F}_{1}$ and $\mathrm{S}_{1} \mathrm{~F}_{3}$ and the lowest weight of cormels plant ${ }^{-1}$ was obtained from $\mathrm{S}_{3} \mathrm{~F}_{2}(64 \mathrm{~g})$ treatment. In 2013, the highest weight of cormels plant ${ }^{-1}$ was recorded in $\mathrm{S}_{2} \mathrm{~F}_{1}(200 \mathrm{~g})$ which was statistically similar with the $S_{1} F_{2}$ and the lowest weight of number of cormels plant ${ }^{-1}$ was obtained from $\mathrm{S}_{3} \mathrm{~F}_{2}(83.3 \mathrm{~g})$ treatment. At Ishurdi, weight of cormels plant $^{-1}$ in different treatments varied significantly in both the years $(2012$ \& 2013) (Table 4). In 2012, the maximum weight of cormels plant ${ }^{-1}$ was recorded in $\mathrm{S}_{1} \mathrm{~F}_{3}(245 \mathrm{~g})$ which was statistically similar with the treatment of $\mathrm{S}_{2} \mathrm{~F}_{3}$ and the lowest weight of cormels plant ${ }^{-1}$ was obtained from $\mathrm{S}_{3} \mathrm{~F}_{2}(187.50 \mathrm{~g})$ treatment. In 2013, the highest weight of cormels plant ${ }^{-1}$ was recorded in $\mathrm{S}_{1} \mathrm{~F}_{3}(268.47 \mathrm{~g})$ which was identical with $\mathrm{S}_{2} \mathrm{~F}_{3}$ and the lowest weight of cormels plant ${ }^{-1}$ was obtained from $\mathrm{S}_{3} \mathrm{~F}_{2}(210.97 \mathrm{~g})$ treatment. The results revealed that wider spacing $(60 \mathrm{~cm} \times 60 \mathrm{~cm})$ gave the maximum weight of cormels plant ${ }^{-1}$ and closer spacing $(60 \mathrm{~cm} \times 30 \mathrm{~cm})$ gave the lowest weight. This is in agreement with the results of Mannan et al. (1988) and Dhar (1989). 
Table 2. Combined effect of spacing and fertilizer on yield contributing characters of mukhikachu at Joydebpur in kharif 2012 and 2013

\begin{tabular}{l|c|c|c|c|c|c|c|c}
\hline \multirow{2}{*}{ Treatment } & \multicolumn{2}{|c|}{$\begin{array}{c}\text { No. of } \\
\text { secondary } \\
\text { corms plant }^{-1}\end{array}$} & \multicolumn{2}{c|}{$\begin{array}{c}\text { Weight of } \\
\text { secondary } \\
\text { corms plant }^{-1}(\mathrm{~g})\end{array}$} & \multicolumn{2}{c|}{$\begin{array}{c}\text { No. of cormels } \\
\text { plant }^{-1}\end{array}$} & \multicolumn{2}{|c}{$\begin{array}{c}\text { Weight of cormels } \\
\text { plant }^{-1}(\mathrm{~g})\end{array}$} \\
\cline { 2 - 9 } & 2012 & 2013 & 2012 & 2013 & 2012 & 2013 & 2012 & 2013 \\
\hline $\mathrm{S}_{1} \mathrm{~F}_{1}$ & 4.50 & 5.13 & 270.6 & 230.1 & 27.80 & 13.53 & 576.6 & 432.5 \\
$\mathrm{~S}_{1} \mathrm{~F}_{2}$ & 4.47 & 3.80 & 259.3 & 220.4 & 28.07 & 13.07 & 585.3 & 439.0 \\
$\mathrm{~S}_{1} \mathrm{~F}_{3}$ & 4.80 & 3.60 & 274.0 & 232.9 & 28.40 & 12.20 & 594.0 & 445.5 \\
$\mathrm{~S}_{2} \mathrm{~F}_{1}$ & 4.80 & 3.87 & 244.6 & 208.0 & 26.27 & 13.27 & 540.0 & 405.0 \\
$\mathrm{~S}_{2} \mathrm{~F}_{2}$ & 4.43 & 3.53 & 242.6 & 206.3 & 25.67 & 12.47 & 534.0 & 400.5 \\
$\mathrm{~S}_{2} \mathrm{~F}_{3}$ & 5.13 & 4.13 & 256.0 & 217.6 & 26.73 & 14.60 & 547.0 & 410.3 \\
$\mathrm{~S}_{3} \mathrm{~F}_{1}$ & 5.00 & 3.73 & 233.3 & 198.3 & 24.80 & 14.93 & 593.3 & 445.0 \\
$\mathrm{~S}_{3} \mathrm{~F}_{2}$ & 4.07 & 4.00 & 234.6 & 199.5 & 24.53 & 10.07 & 574.6 & 431.0 \\
$\mathrm{~S}_{3} \mathrm{~F}_{3}$ & 4.73 & 4.00 & 240.6 & 204.6 & 26.67 & 13 & 572.0 & 429.0 \\
\hline $\mathrm{LSD}(0.05)$ & $\mathrm{NS}$ & 1.54 & $\mathrm{NS}$ & 25.27 & $\mathrm{NS}$ & 2.98 & 48.46 & $\mathrm{NS}$ \\
$\mathrm{CV}(\%)$ & 8.90 & 9.91 & 7.2 & 8.2 & 5.80 & 5.90 & 10.9 & 5.12 \\
\hline
\end{tabular}

$\mathrm{S}_{1}=60 \mathrm{~cm} \times 60 \mathrm{~cm}, \mathrm{~S}_{2}=60 \mathrm{~cm} \times 45 \mathrm{~cm}, \mathrm{~S}_{3}=60 \mathrm{~cm} \times 30 \mathrm{~cm}, \mathrm{~F}_{1}=$ Recommended fertilizer dose (3000-97-27-81-18 $\mathrm{kg} \mathrm{ha}^{-1}$ of CD- NPKS), $\mathrm{F}_{2}=25 \%$ less than recommended dose and $\mathrm{F}_{3}=25 \%$ higher than recommended dose

Table 3. Combined effect of spacing and fertilizer on yield contributing characters of mukhikachu at Jamalpur in kharif 2012 and 2013

\begin{tabular}{|c|c|c|c|c|c|c|c|c|}
\hline \multirow[t]{2}{*}{ Treatment } & \multicolumn{2}{|c|}{$\begin{array}{c}\text { No. of } \\
\text { secondary } \\
\text { Corms plant }^{-1} \\
\end{array}$} & \multicolumn{2}{|c|}{$\begin{array}{c}\text { Weight of } \\
\text { secondary } \\
\text { Corms plant }^{-1}(\mathrm{~g})\end{array}$} & \multicolumn{2}{|c|}{$\begin{array}{l}\text { No. of cormels } \\
\text { plant }^{-1}\end{array}$} & \multicolumn{2}{|c|}{$\begin{array}{l}\text { Weight of cormel } \\
\text { plant }^{-1}(\mathrm{~g})\end{array}$} \\
\hline & 2012 & 2013 & 2012 & 2013 & 2012 & 2013 & 2012 & 2013 \\
\hline $\mathrm{S}_{1} \mathrm{~F}_{1}$ & 5.40 & 8.13 & 353.30 & 373.3 & 8.50 & 17.80 & 123.30 & 106.60 \\
\hline $\mathrm{S}_{1} \mathrm{~F}_{2}$ & 3.40 & 6.00 & 246.70 & 453.3 & 7.13 & 11.50 & 67.30 & 193.30 \\
\hline $\mathrm{S}_{1} \mathrm{~F}_{3}$ & 4.33 & 6.93 & 393.30 & 456.6 & 8.90 & 13.90 & 118 & 163.30 \\
\hline $\mathrm{S}_{2} \mathrm{~F}_{1}$ & 4.60 & 8.00 & 320.0 & 426.6 & 9.90 & 14.90 & 124.70 & 200 \\
\hline $\mathrm{S}_{2} \mathrm{~F}_{2}$ & 3.60 & 6.93 & 330.0 & 316.6 & 7.30 & 12.40 & 75.30 & 120 \\
\hline $\mathrm{S}_{2} \mathrm{~F}_{3}$ & 5.13 & 7.70 & 386.70 & 356.6 & 7.50 & 10.90 & 77.30 & 118 \\
\hline $\mathrm{S}_{3} \mathrm{~F}_{1}$ & 4.0 & 6.10 & 206.70 & 246.6 & 7.50 & 9.90 & 91.30 & 103.30 \\
\hline $\mathrm{S}_{3} \mathrm{~F}_{2}$ & 4.80 & 6.66 & 290.0 & 336.6 & 6.60 & 9.50 & 64.0 & 83.30 \\
\hline $\mathrm{S}_{3} \mathrm{~F}_{3}$ & 4.20 & 6.63 & 300.0 & 333.3 & 6.90 & 10.40 & 78 & 116.60 \\
\hline LSD (0.05) & NS & NS & 56.90 & 53.3 & NS & 2.18 & 22.70 & 28.30 \\
\hline CV $(\%)$ & 8.01 & 12.40 & 10.20 & 8.24 & 12.20 & 0.94 & 14.0 & 11.87 \\
\hline
\end{tabular}

$\mathrm{S}_{1}=60 \mathrm{~cm} \times 60 \mathrm{~cm}, \mathrm{~S}_{2}=60 \mathrm{~cm} \times 45 \mathrm{~cm}, \mathrm{~S}_{3}=60 \mathrm{~cm} \times 30 \mathrm{~cm}, \mathrm{~F}_{1}=$ Recommended fertilizer dose (3000-97-27-81-18 $\mathrm{kg} \mathrm{ha}^{-1}$ of CD- N-P-K-S), $\mathrm{F}_{2}=25 \%$ less than recommended dose and $\mathrm{F}_{3}=25 \%$ higher than recommended dose 
Table 4. Combined effect of spacing and fertilizer on yield contributing characters of mukhikachu at Ishurdi in kharif 2012 and 2013

\begin{tabular}{|c|c|c|c|c|c|c|c|c|}
\hline \multirow[t]{2}{*}{ Treatment } & \multicolumn{2}{|c|}{$\begin{array}{c}\text { No. of } \\
\text { Secondary } \\
\text { corms plant }^{-1}\end{array}$} & \multicolumn{2}{|c|}{$\begin{array}{c}\text { Weight of } \\
\text { secondary } \\
\text { corms plant }^{-1}(\mathrm{~g}) \\
\end{array}$} & \multicolumn{2}{|c|}{$\begin{array}{c}\text { No. of cormels } \\
\text { plant }^{-1}\end{array}$} & \multicolumn{2}{|c|}{$\begin{array}{l}\text { Weight of } \\
\text { cormels plant }^{-1} \\
\text { (g) }\end{array}$} \\
\hline & 2012 & 2013 & 2012 & 2013 & 2012 & 2013 & 2012 & 2013 \\
\hline${ }_{1} \mathrm{~F}_{1}$ & 5.10 & 5.75 & 12350 & 143.73 & 1570 & 16.27 & 230.50 & 253.96 \\
\hline${ }_{1} \mathrm{~F}_{2}$ & 4.80 & 5.45 & 119.50 & 139.72 & & & & 235.47 \\
\hline $\mathrm{S}_{1} \mathrm{~F}_{3}$ & 5.20 & 5.86 & 135.50 & 155.72 & 16.88 & 17.46 & 245.00 & 268.47 \\
\hline $\mathrm{S}_{2} \mathrm{~F}_{1}$ & 4.80 & 5.45 & 115.50 & 135.71 & 14.90 & 15.48 & 219.50 & 242.99 \\
\hline $\mathrm{S}_{2} \mathrm{~F}_{2}$ & 4.70 & & & & & & & \\
\hline $\mathrm{S}_{2} \mathrm{~F}_{3}$ & 5.0 & 5.65 & 135.00 & 155.21 & 15.10 & 15.68 & 236.00 & 259.46 \\
\hline $\mathrm{S}_{3} \mathrm{~F}_{1}$ & 5.0 & 5.31 & 111.00 & 130.72 & 14.00 & 14.88 & 212.80 & 236.29 \\
\hline $\mathrm{S}_{3} \mathrm{~F}_{2}$ & 3.70 & 4.35 & & & 13.90 & & & 210.97 \\
\hline $\mathrm{S}_{3} \mathrm{~F}_{3}$ & 4.90 & 5.56 & 112.00 & 132.22 & 14.70 & 15.30 & 223.00 & 246.48 \\
\hline $\operatorname{LSD}(0.05)$ & 0.55 & 0.54 & 6.50 & 1.84 & 1.49 & 1.50 & 13.60 & 13.61 \\
\hline CV $(\%)$ & 6.63 & 5.80 & 3.20 & 2.73 & 5.72 & 5.54 & 3.50 & 3.24 \\
\hline
\end{tabular}

$\mathrm{S}_{1}=60 \mathrm{~cm} \times 60 \mathrm{~cm}, \mathrm{~S}_{2}=60 \mathrm{~cm} \times 45 \mathrm{~cm}, \mathrm{~S}_{3}=60 \mathrm{~cm} \times 30 \mathrm{~cm}, \mathrm{~F}_{1}=$ Recommended fertilizer dose (3000-97-27-81-18 $\mathrm{kg} \mathrm{ha}^{-1}$ of CD-N-P-K-S), $\mathrm{F}_{2}=25 \%$ less than recommended dose and $\mathrm{F}_{3}=25 \%$ higher than recommended dose

\section{Edible yield of mukhikachu}

The combination of spacing and fertilizer treatments put significant effect on edible yield of mukhikachu at all locations (Table 5). At Joydebpur, different treatments varied significantly in respect of edible yield in both the years (2012 $\&$ 2013). In 2012, the maximum edible yield was recorded in $\mathrm{S}_{3} \mathrm{~F}_{3}\left(19.87 \mathrm{t} \mathrm{ha}^{-1}\right)$ closely followed by $\mathrm{S}_{3} \mathrm{~F}_{1}\left(16.23 \mathrm{tha}^{-1}\right)$ and the lowest edible yield was obtained in $\mathrm{S}_{1} \mathrm{~F}_{2}\left(14.94 \mathrm{t} \mathrm{ha}^{-1}\right)$ treatment. In 2013, the highest edible yield was recorded in $\mathrm{S}_{3} \mathrm{~F}_{3}\left(20.21 \mathrm{t} \mathrm{ha}^{-1}\right)$ which was identical with $\mathrm{S}_{3} \mathrm{~F}_{1}\left(19.92 \mathrm{t} \mathrm{ha}^{-1}\right)$ and the lowest edible yield was obtained from $\mathrm{S}_{1} \mathrm{~F}_{2}\left(9.54 \mathrm{t} \mathrm{ha}^{-1}\right)$ treatment. Maximum edible yield (two years average) was obtained from $\mathrm{S}_{3} \mathrm{~F}_{3}\left(20.04 \mathrm{t} \mathrm{ha}^{-1}\right)$ closely followed by $\mathrm{S}_{3} \mathrm{~F}_{1}\left(19.58 \mathrm{t} \mathrm{ha}^{-1}\right)$ and the lowest (average of two years) from $\mathrm{S}_{1} \mathrm{~F}_{2}(12.24 \mathrm{tha}$ $\left.{ }^{1}\right)$ treatment. At Jamalpur, the highest edible yield was recorded in $S_{3} F_{3}(21.60 t$ $\mathrm{ha}^{-1}$ in 2012 and $19.90 \mathrm{t} \mathrm{ha}^{-1}$ in 2013) which was identical with the treatments $\mathrm{S}_{2} \mathrm{~F}_{2}, \mathrm{~S}_{3} \mathrm{~F}_{1}$ and $\mathrm{S}_{3} \mathrm{~F}_{2}$ in 2012 and $\mathrm{S}_{3} \mathrm{~F}_{1}$ and $\mathrm{S}_{3} \mathrm{~F}_{2}$ in 2013. The lowest edible yield was obtained from $\mathrm{S}_{1} \mathrm{~F}_{2}$ treatment (11.80 tha $\mathrm{ha}^{-1}$ in 2012 and $15.30 \mathrm{t} \mathrm{ha}^{-1}$ in 2013). From the two years average data, it was revealed that the maximum edible yield was recorded in $\mathrm{S}_{3} \mathrm{~F}_{3}\left(20.75 \mathrm{tha}^{-1}\right)$ closely followed by $\mathrm{S}_{3} \mathrm{~F}_{2}\left(19.05 \mathrm{tha}^{-1}\right)$ and the lowest was found in $\mathrm{S}_{1} \mathrm{~F}_{2}\left(14.30 \mathrm{t} \mathrm{ha}^{-1}\right)$ treatment. At Ishurdi location, the highest 
edible yield was found in $\mathrm{S}_{3} \mathrm{~F}_{3}$ (15.94 and 17.32 tha $^{-1}$ in 2012 and 2013, respectively) closely followed by $\mathrm{S}_{2} \mathrm{~F}_{3}$ and $\mathrm{S}_{3} \mathrm{~F}_{1}$ treatments. The lowest edible yield was obtained from $S_{1} F_{2}$ (12.09 $\mathrm{t} \mathrm{ha}^{-1}$ in 2012 and $13.47 \mathrm{t} \mathrm{ha}^{-1}$ in 2013). On the basis of two years average data, the maximum edible yield was recorded in $\mathrm{S}_{3} \mathrm{~F}_{3}\left(16.63 \mathrm{tha}^{-1}\right)$ which was identical with $\mathrm{S}_{3} \mathrm{~F}_{1}\left(16.49 \mathrm{t} \mathrm{ha}^{-1}\right)$ and the lowest was found in $\mathrm{S}_{1} \mathrm{~F}_{2}\left(12.78 \mathrm{t} \mathrm{ha}^{-1}\right)$ treatment. As the soil nutrient content of Jamalpur was comparatively poor compared to Joydepur and Ishurdi (Table 1), it required $25 \%$ higher than the recommended dose for maximum yield of mukhikachu. Edible yield increased at closer spacing over wider spacing may solely be ascribed on the function of the highest plant density per unit area of land.

Table 5. Combined effect of spacing and fertilizer on edible yield of mukhikachu at Joydebpur, Jamalpur and Ishurdi locations

\begin{tabular}{l|c|c|c|c|c|c|c|c|c}
\hline \multirow{2}{*}{ Treatment } & \multicolumn{9}{c|}{ Edible yield $\left(\mathrm{t} \mathrm{ha}^{-1}\right)$} \\
\cline { 2 - 10 } & \multicolumn{3}{|c|}{ Joydebpur } & \multicolumn{3}{c}{ Jamalpur } & \multicolumn{3}{c}{ Ishurdi } \\
\cline { 2 - 11 } & 2012 & 2013 & Average & 2012 & 2013 & Average & 2012 & 2013 & Average \\
\hline $\mathrm{S}_{1} \mathrm{~F}_{1}$ & 15.30 & 11.52 & 13.41 & 15.90 & 15.30 & 15.60 & 13.13 & 14.52 & 13.83 \\
$\mathrm{~S}_{1} \mathrm{~F}_{2}$ & 14.94 & 9.54 & 12.24 & 11.80 & 16.80 & 14.30 & 12.09 & 13.47 & 12.78 \\
$\mathrm{~S}_{1} \mathrm{~F}_{3}$ & 15.25 & 11.43 & 13.34 & 14.20 & 15.70 & 14.95 & 13.42 & 14.81 & 14.12 \\
$\mathrm{~S}_{2} \mathrm{~F}_{1}$ & 17.23 & 11.51 & 14.37 & 15.40 & 17.10 & 16.25 & 14.29 & 15.67 & 14.98 \\
$\mathrm{~S}_{2} \mathrm{~F}_{2}$ & 15.20 & 10.62 & 12.91 & 19.00 & 15.40 & 17.20 & 12.76 & 14.14 & 13.45 \\
$\mathrm{~S}_{2} \mathrm{~F}_{3}$ & 16.82 & 14.41 & 15.62 & 17.60 & 15.60 & 16.60 & 14.88 & 16.25 & 15.57 \\
$\mathrm{~S}_{3} \mathrm{~F}_{1}$ & 19.23 & 19.92 & 19.58 & 19.90 & 17.60 & 18.75 & 15.80 & 17.18 & 16.49 \\
$\mathrm{~S}_{3} \mathrm{~F}_{2}$ & 18.49 & 13.32 & 15.91 & 19.20 & 18.90 & 19.05 & 14.08 & 15.47 & 14.78 \\
$\mathrm{~S}_{3} \mathrm{~F}_{3}$ & 19.87 & 20.21 & 20.04 & 21.60 & 19.90 & 20.75 & 15.94 & 17.32 & 16.63 \\
\hline $\mathrm{LSD}_{(0.05)}$ & 0.90 & 1.34 & 1.21 & 2.77 & 2.91 & 1.82 & 1.67 & 1.66 & 1.32 \\
$\mathrm{CV}(\%)$ & 3.10 & 10.12 & 11.20 & 9.08 & 7.79 & 10.15 & 6.85 & 6.23 & 9.56 \\
\hline
\end{tabular}

$\mathrm{S}_{1}=60 \mathrm{~cm} \times 60 \mathrm{~cm}, \mathrm{~S}_{2}=60 \mathrm{~cm} \times 45 \mathrm{~cm}, \mathrm{~S}_{3}=60 \mathrm{~cm} \times 30 \mathrm{~cm}, \mathrm{~F}_{1}=$ Recommended fertilizer dose (3000-97-27-81-18 $\mathrm{kg} \mathrm{ha}^{-1}$ of CD-N-P-K-S), $\mathrm{F}_{2}=25 \%$ less than recommended dose and $\mathrm{F}_{3}=25 \%$ higher than recommended dose

It revealed that at all three locations, the maximum edible yield were recorded in $\mathrm{S}_{3} \mathrm{~F}_{3}$ treatment. Imran et al. (2010) obtained the maximum yield of cormels (37.29 $\mathrm{t} \mathrm{ha}^{-1}$ ) by fertilizing Compost, Urea, TSP and MoP @ 15000, 62.5, 62.5 and $50 \mathrm{~kg} \mathrm{ha}^{-1}$. Gill et al. (2005) got the highest yield of mukhikachu at closer spacing than at wider spacing. This is also in agreement with the findings of Basak et al. (1999) who evaluated multi location trial of Colocasia esculenta under different spacing and fertilizer level and found that per plant yield was higher in wider spacing but total yield was higher in the closer spacing. Atiquzzanman (2008) obtained the maximum yield of corms and cormel (edible 
yield) (20.24 t ha-1) at $60 \times 25 \mathrm{~cm}$ spacing whereas Sikder (2014) got maximum yield (31.8 $\mathrm{t} \mathrm{ha}^{-1}$ from $60 \mathrm{~cm}$ x $40 \mathrm{~cm}$ spacing. Oglbonna et al. (2015) stated that closest spacing gave the highest yield of taro.

Table 6. Economic analysis of mukhikachu under variable spacing and fertilizer management at different locations (two years average)

\begin{tabular}{|c|c|c|c|c|c|c|c|c|c|}
\hline \multirow[b]{2}{*}{ Treatment } & \multicolumn{3}{|c|}{ Gross return $\left(\mathrm{Tk} \mathrm{ha}^{-1}\right)$} & \multicolumn{3}{|c|}{ Cultivation cost $\left(\mathrm{Tk} \mathrm{ha}^{-1}\right)$} & \multicolumn{3}{|c|}{ Benefit Cost Ratio } \\
\hline & 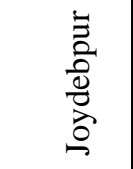 & $\begin{array}{l}: \bar{\Xi} \\
\stackrel{\Xi}{\Xi} \\
\underline{\Xi}\end{array}$ & 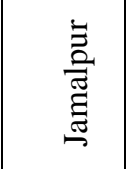 & 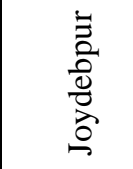 & 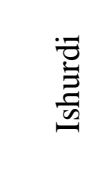 & 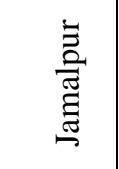 & 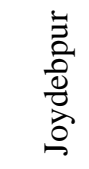 & 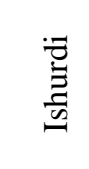 & 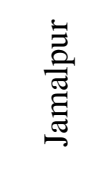 \\
\hline $\mathrm{S}_{1} \mathrm{~F}_{1}$ & 201150 & 207375 & 234000 & 92364 & 68465 & 88456 & 2.18 & 3.03 & 2.64 \\
\hline $\mathrm{S}_{1} \mathrm{~F}_{2}$ & 183600 & 191700 & 214500 & 89780 & 65337 & 86314 & 2.05 & 2.94 & 2.48 \\
\hline $\mathrm{S}_{1} \mathrm{~F}_{3}$ & 200100 & 211725 & 224250 & 94940 & 71594 & 91594 & 2.11 & 2.96 & 2.45 \\
\hline $\mathrm{S}_{2} \mathrm{~F}_{1}$ & 215550 & 224700 & 243750 & 96864 & 70465 & 92031 & 2.23 & 3.19 & 2.65 \\
\hline $\mathrm{S}_{2} \mathrm{~F}_{2}$ & 193650 & 201750 & 258000 & 94280 & 67337 & 88889 & 2.06 & 3.00 & 2.90 \\
\hline $\mathrm{S}_{2} \mathrm{~F}_{3}$ & 234225 & 233475 & 249000 & 99440 & 73594 & 95169 & 2.36 & 3.17 & 2.62 \\
\hline$S_{31}$ & 293625 & 247350 & 281250 & 100204 & 72465 & 94268 & 2.93 & 3.42 & 2.98 \\
\hline $\mathrm{S}_{3} \mathrm{~F}_{2}$ & 238575 & 221625 & 285750 & 99780 & 69337 & 94014 & 2.39 & 3.20 & 3.03 \\
\hline $\mathrm{S}_{3} \mathrm{~F}_{3}$ & 300600 & 249450 & 311250 & 104940 & 75594 & 99794 & 2.69 & 3.30 & 3.12 \\
\hline
\end{tabular}

$\mathrm{S}_{1}=60 \mathrm{~cm} \times 60 \mathrm{~cm}, \mathrm{~S}_{2}=60 \mathrm{~cm} \times 45 \mathrm{~cm}, \mathrm{~S}^{3}=60 \mathrm{~cm} \times 30 \mathrm{~cm}, \mathrm{~F}_{1}=$ Recommended fertilizer dose (3000-97-27-81-18 $\mathrm{kg} \mathrm{ha}^{-1}$ of CD-N-P-K-S) , $\mathrm{F}_{2}=25 \%$ less than recommended dose and $\mathrm{F}_{3}=25 \%$ higher than recommended dose and Produce price $=$ Tk. $15 \mathrm{~kg}^{-1}$

\section{Economic analysis}

The maximum gross return was found in $25 \%$ higher than the recommended fertilizer dose (96-27-81-18 $\mathrm{kg} \mathrm{ha}^{-1}$ of NPKS) with $60 \mathrm{~cm} \mathrm{x} 30 \mathrm{~cm}$ spacing (Tk. 300600, Tk. 249450 and Tk. 311250 at Joydebpur, Ishurdi and Jamalpur, respectively) and the lowest gross return was found in $25 \%$ less than the recommended dose with $60 \mathrm{~cm} \mathrm{x} 45 \mathrm{~cm}$ spacing (Tk. 201150, Tk. 207375 and Tk. 234000 at Joydebpur, Ishurdi and Jamalpur, respectively) (Table 6). The highest cultivation cost was found in $25 \%$ higher than the recommended dose with $60 \mathrm{~cm}$ x $30 \mathrm{~cm}$ spacing (Tk. 104940, Tk. 75594 and Tk. 99794 at Joydebpur, Ishurdi and Jamalpur, respectively) and the lowest cultivation cost was found in $25 \%$ less than the recommended dose with $60 \mathrm{~cm}$ x $45 \mathrm{~cm}$ spacing (Tk. 89780, Tk. 65337 and Tk. 86314 at Joydebpur, Ishurdi and Jamalpur, respectively). The maximum benefit-cost ratio was recorded from the 
recommended fertilizer dose with $60 \mathrm{~cm}$ x $30 \mathrm{~cm}$ spacing at Joydebpur (2.93) and Ishurdi (3.42), while at Jamalpur the maximum benefit-cost ratio was observed from $25 \%$ higher than the recommended fertilizer dose with $60 \mathrm{~cm} \mathrm{x} 30 \mathrm{~cm}$ spacing (3.12).

\section{Conclusion}

The results of the experiment led to the conclusion that the farmers of Jodebpur and Ishurdi region might be suggested to use the recommended fertilizer dose of $3000-96-27-81-18 \mathrm{~kg} \mathrm{ha}^{-1}$ of CD-N-P-K-S in combination with $60 \mathrm{~cm} \times 30 \mathrm{~cm}$ spacing while the farmers of Jamalpur region suggested to cultivate mukhikachu by using $25 \%$ higher than the recommended fertilizer dose at $60 \mathrm{~cm} \times 30 \mathrm{~cm}$ spacing.

\section{References}

Atiquzzanmam, M., M. M. Ali., M. A. Mondal, M. Z. F. A. Begum and Q. Y. Akhter. 2008. Effect of spacing on the growth and yield of 'Mukhikachu'. J. Agrofor. Enviro. 2(1): 1-6.

Basak, N. C. and M. A. Maleque. 1992. Effect of spacing on the rhizome and stolon yield of Pani Kachu (var. Latiraj). Research report, On Farm Division, Kishoregonj, BARI. Pp.1-7.

Basak, N. C., M. M. R, Khan,. and A. H., Sarker. 1999. Effects of spacings and fertilizers on the agro-economic performance of Panikachu. Bangladesh J. Train. Dev. 12(1/2): 155-160.

BBS, 2011. Monthly Statistical Bulletin, Bangladesh Bureau of Statistics. Ministry of Planning, People's Republic of Bangladesh. Dhaka. P.55.

Bose, T. K. and M. G. Som. 1986. Vegetable crops in India. Naya Prokash, Calcutta700006, India. Pp. 733-737.

Dhar, M. 1989. Effect of plant spacing and system of planting on the growth and yield of Mukhi Kachu (Colocasia esculenta). M. Sc. (Ag.) Thesis. Dept. Hort., Bangladesh Agric. Univ., Mymensingh, Pp. 65-72.

FAO (Food and Agriculture Organization). 1999. Quarterly Bulletin of Statistics. Food and Agriculture Organization of the United Nations, Rome, Italy. 12(3/4): 45.

FRG (Fertilizer Recommendation Guide). 2005. Fertilizer Recommendation Guide, Bangladesh Agricultural Research Council (BARC), New Airport Road, Farmgate, Dhaka 1215. 101p.

Gill, B. S., Randhawa, G. S. and Saini, S. S. 2005. Optimizing the agronomic requirements of taro (Colocasia esculenta) for Punjab. Indian J. Agron. 50 (2): 170172.

Gomez, H. C. and A. A. Gomez. 1984. Statistical Procedures for Agric. Res. $2^{\text {nd }}$ Edn., John Wiley and Sons. New York, USA. 680 p. 
Imran, S. M., M. A. Sattar, M. R. Islam, M. M. A. Hossain and M. S. Alam. 2010. Effect of different organic and inorganic fertilizers on growth and yield of mukhikachu (Colocasia esculenta) cv. Salikachu. J. Agrofor. Environ. 4(2): 53-56.

Mannan, M. A., A. K. Sarkar and M. M. Rashid. 1988. Effect of spacing in single and double row systems on the yield and profitability of Mukhi Kachu. Bangladesh J. Agric. Res. 13(2): 89-96.

Mitra, S. K., M. K. Sadhu and T. K. Bose. 1990. Nutrition of vegetable crops. Naya Prokash, Calcutta. Pp. 327-330.

Mohankumar, C. R., N. sadananda and P. saraswathy. 1991. Effect of levels of NPK and time of application of $\mathrm{N}$ and $\mathrm{K}$ on the yield of taro (Colocasia esculenta $\mathrm{L}$. Schott). J. Root crops. 16 (1): 33-38.

Ogbonna, P. E., K. O. Orji, N. J. Nweze and P. I. Opata. 2015. Effect of plant space on plant population at harvest and tuber yield in taro (Colocasia esculenta L.). African J. Agril. Res. 10(5): 308-316.

Rashid, M. M. 1999. Sabjibiggayan (In Bengali). Rashid Publishing House, 94, Puraton DOHS, Dhaka 1206. Pp. 448-452.

Salam, M.A., M. M. Patwary, M. M. Rahman, M. D. Hossain and M. Saifullah. 2003. Profitability of mukhikachu (Colocasia esculenta) production as influenced by different doses and time of application of urea and muriate of potash. Asian J. Plant Sci. 2(2): 233-236.

Siddique, M. A., M. Dhar and M. O. Rabbani. 1988. Effect of seed cormel size and plant spacing on the yield of Mukhi kachu. Bangladesh J. Agril Res. 13 (1): 31-36.

Sikder, R. K., M. I. Asif, Touhiduzzaman, H. Mehraj and A. F. M. Jamaluddin. 2014. Response of mukhikachu (Colocasia esculenta L.) cv. Bilashi to plant spacing. Int. J. Expt. Agric. (4): 14-18.

Suminarti, N. E., B. Ariffen, B. Guritno and M. L. Rayes. 2016. Effect of fertilizer application and plant density on physiological aspect and yield of taro (Colocasia esculenta (L.) Scott var. Antiquorum). Int. J. Agril Res. 11(1): 32-59. 